\title{
Impact of Culture on Rural Built Environment
}

\author{
Srinivas Daketi, Abdul Razak Mohamed, Ramesh Srikonda
}

\begin{abstract}
The term "built environment" refers to the human made or modified physical surroundings in which people live, work and play. These places and spaces include our homes, communities, schools, workplaces, parks/recreations areas, business areas and transportation systems, and vary in size from large-scale urban areas to smaller rural developments. Based on human activities, the environment was created to obtain the basic needs of people. The regular human activities for many generations to prepare their needs are considered as culture. Hence based on culture, the environment was built and maintained for future generation. Regions are separated into two types based on production occurs in rural area and trading developed in urban. In olden days, most of the places are rural because of the undevelopment in transport system. The activities involved in preparing food, shelter and other needs are the common factors to build rural environment. Natural resources are the basic factor that decides the build environment and culture of human in rural regions. By analyzing the natural resources, the cultural impacts are determined based on building environment in rural areas.
\end{abstract}

Index Terms: built environment, culture, natural resource.

\section{INTRODUCTION}

The built environment provides the setting and backdrop by which we live our lives, and impacts on our senses, our emotions, participation in physical activity and community life, our sense of community, and general wellbeing. Buildings and spaces, which we 'read', generate meanings as we pass through them. Subsequently, cultural maintainability looks at approaches to enhance human lives and providespractical legacy for next generations. Society can't proceed with the new attitude towards asset misuse on the off chance that has the desire to give next generations the capacity to address their own particular issues. Cultural esteem shapes the society's lifestyle and in this manner can possibly realize the change of attitudes expected to guarantee the accomplishment of feasible improvement. Culture contributes to the working of exuberant urban communities and groups where individuals can live, work and assume a noteworthy part in supporting social and monetary prosperity.

The issue of the part of the culture in a maintainable built

Revised Manuscript Received on July 08, 2019.

Srinivas Daketi, Assistant Professor, Department of Architecture, School of Planning and Architecture Vijayawada. amst1920@gmail.com

Dr.AbdulRazak Mohamed, Professor, Department of Architecture, School of Planning and Architecture Vijayawada.

Dr.RameshSrikonda, Professor, Department of Architecture, School of Planning and Architecture Vijayawada.

environment is winding up noticeably more essential because of the developing effect of the built environment in accomplishing society's practical improvement. Society faces natural difficulties, including environmental change and urban populace development and reacting to these interconnected difficulties is at the focal point of society's attentiveness toward its future. This part intends to analyze writing to propel this rising zone of research by mapping the linkages between the idea of culture, feasible advancement and the built environment.

A survey of an extensive variety of important writing identifying with culture, maintain and the built environment is exhibited. This survey concentrated on applicable productions in scholarly writing that give proof of the part of the culture in an economically manufactured condition. The survey of writing highlights the expanding acknowledgment of culture as effective and critical perspective in encouraging financial, social and natural measurements of advancement. Culture is a key component in the idea of practical advancement as it casings individuals' connections and states of mind towards the built and the natural environment. Supportable advancement is an essential piece of the general public and culture; influencing all parts of operations in the built environment. This section gives an inside and out knowledge into the commitment of culture and places culture as the conceivable fourth measurement of supportability and a fundamental piece of ecological, financial and social measurements of economic advancement (Opoku, 2015).

The built environment puts major pressure on the natural environment; its role in transitioning to a circular economy (CE) is therefore fundamental. However, current CE research tends to focus either on the macro-scale, such as eco-parks, or the micro-scale, such as manufactured products, with the risk of ignoring the additional impacts and potentials at the mesoscale of individual buildings (Pomponi \& Moncaster, 2017).

Two aspects are worth considering when framing building research from a circular economy perspective. Firstly, solutions devised and engineered for short-lived products are unlikely to be applicable to buildings. The 'manufacture' and useful life phases of a building extend over a significant time span. Evidence of this can be found in figures about the existing building stock. The World Health Organization, in recognition of the role that housing conditions play on health, has dedicated a specific topic area to explore this relationship. It suggests that the interplay between housing and health can be understood in a number of different dimensions including environment,

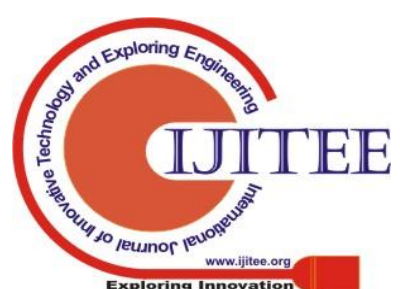


community, and economics.

\section{LITERATURE REVIEW}

\section{A. Studies related to building environment}

Opoku (2015)analyzed the role of culture in the sustainable build environment. Sustainability efforts that once were characterized by environmental, social and economic issues only now see the inclusion of culture as a holistic benefit to sustainable development. Finally, the literature review provides the opportunities from an academic perspective to empirically further investigate the contribution of culture to the understanding of sustainable development and the built environment in future research.

Pomponi and Moncaster (2017) proposed a framework on the circular economy for built environment. A fundamental definition of $\mathrm{CE}$ was studied and frames $\mathrm{CE}$ to built environment. A critical literature review was formed on the basis to identify and frame such fundamental dimensions are used to capture current discourse on the sustainability of the built environment. It is proved that a valuable tool is used to cluster existing initiatives and highlight missing links for interdisciplinary endeavors. However, the theoretical foundations and a stepping stone are to be contributed to shaping future research initiatives.

Pacheco-Torgal (2017) studied and about energy sources and usage on built environment and analyzed to reduce energy source using advanced innovative technology. Developments on nano and bio-based innovations are important for an energy-efficient built environment. This review may contribute to enhance the innovation and patenting activity in civil engineering. This may help to foster the creation of high-tech startups for an energy-efficient built environment.

\section{B. Studies related to culture for building environment}

Head et al. (2005)analyzed culture influenced on environment research and management. Undervalued area of environmental humanities research-cultural analysis of the beliefs and practices are focused. Cultural processes are central to environmental attitudes and behaviors are discussed and Qualitative research methods can be used to understand them in depth. Finally, address the practical challenges of environmental sustainability. However, samples on diverse cultural engagements with Australian environments are to be stimulated in future.

Srinivas (2015) studied about culture as well as its impact on rural architecture. The culture is the full range of human behaviors and patterns in the appreciation of good literature, music, art etc. Various built forms, environments and spaces of rural architecture are discussed. The impact of culture on various rural built environments is analyzed. The author concludes that the changes and transformation of the rural built that being occurred due to the various factors such as urbanization and influences of colonies. The evolutionary pattern and households are guided by most of the impact factor called culture. However, the author analyzed rural build environment based on culture but it also dependson the natural resource.

Jayasudha et al. (2014) studied about vernacular dwelling in Thanjavur region of Tamil Nadu in India. Since, various factors such as climate change, geographical location, occupation, culture, and tradition are considered for making structures sustainable. A case study was analyzed based on spatial design, scale, and proportion of building component and integrated with thermal performance during various weather conditions using ECOTECT software. However, the author aims to identify and understand the sustainable principle in traditional and vernacular architecture that could be imbibed and incorporated by builders.

From the above literature have identified three "impact areas" of culture on the local economic environment:

$>$ Direct economic impacts from employment and value generation in the cultural industries and indirect expenditure effect, which are so much larger the more "embedded" in the local are cultural professions

$>$ Induced effects of cultural activities on the quality of a place, among which the tourist attractiveness, which leverages additional visitor expenditure, but also the location amenities for companies

$>$ "Creative inputs" accruing to the local networks of production (both to products and processes of production, or organisational models). These are "cultivated" in a lively and stimulating cultural environment where a creative class develops, attracted by tolerance, openness, educational and social opportunities.

\section{Major research themes and dimensions of the built environment.}

The studies examinediscuss various aspects of travel behavior and cover different dimensions of the built environment. Travel time, travel distance, trip frequency, daily commuting time and distance and the preferred transport mode are among the most studied aspects of travel behavior. However, although travel is mostly driven by activities, there has been only a limited effort in terms of activity behavior, possibly due to a lack of data as most cities only conduct survey on travel behavior, not on activity behavior. Nevertheless, some research has touched upon aspects of activity-behavior, including time use for maintenance and recreation activities (Wang et al., 2011a, 2011b; Zhao \& Chai, 2013). Table 1 lists the major dimensions of the built environment that have been examined in the literature. Jobs-housing relationships appear to be the most studied dimension of the built environment. More than $60 \%$ of the reviewed studies chose jobs-housing relationships as the major research theme. One possible reason for this is China's unique Danwei system that administratively co-locates work and housing. Other popular subjects for study include accessibility to transport facilities, neighborhood or housing types, and population density. Around $30 \%$ of the studies consider one 
of these three dimensions.

\begin{tabular}{|c|l|c|l|}
\hline S.No & $\begin{array}{l}\text { Built environment } \\
\text { measures }\end{array}$ & $\begin{array}{l}\text { Number of } \\
\text { studies }\end{array}$ & Percentage \\
\hline 1. & $\begin{array}{l}\text { Jobs-housing } \\
\text { relationships }\end{array}$ & 33 & $62.3 \%$ \\
\hline 2. & Transport accessibility & 17 & $32.1 \%$ \\
\hline 3. & $\begin{array}{l}\text { Neighborhood } \\
\text { types/housing sources }\end{array}$ & 15 & $28.3 \%$ \\
\hline 4. & Population density & 15 & $28.3 \%$ \\
\hline 5. & Residential location & 11 & $20.8 \%$ \\
\hline 6. & $\begin{array}{l}\text { Service facility } \\
\text { accessibility }\end{array}$ & 11 & $20.8 \%$ \\
\hline 7. & $\begin{array}{l}\text { Residential } \\
\text { zones/districts }\end{array}$ & 6 & $11.3 \%$ \\
\hline 8. & Mixed land use & 4 & $7.5 \%$ \\
\hline 9. & Street design & 3 & $5.7 \%$ \\
\hline
\end{tabular}

Studies of the impact of neighborhood types on travel behavior, 'neighborhood types' as a categorical variable were always included as a major independent variable. Accessibility to employment, transport as well as daily life facilities were often also considered in the studies (Zhao et al., 2010; Feng et al., 2014; Zhao \& Lu, 2011; Yang, 2010; Liu et al., 2014a, 2014b; Ma \& Wang, 2015; Zhang et al., 2014). Population density, as a key feature of urban land use, is also frequently included in the models (Feng et al., 2013, 2014; Yang et al., 2012; Zhao et al., 2010; Liu et al., 2014a, 2014b; Yang, 2010; Zhao, 2014). About 20\% of the studies looked at residential location or accessibility to daily life facilities. By contrast, factors such as the land use mix and street design have received relatively little attention (Wang \& Zhou, 2017).

\section{MODEL SPECIFICATION}

A model specified is a simplified version of the conceptual model, was estimated. Correlation tests were conducted before creating the model. The model results, including model fits, standardized coefficients and significance, are provided. The RMSEA fit index suggests a good fit and CFI fit index suggests an acceptable fit (CFI $=0.938$, RMSEA = 0.035) based on Hu and Bentler (1999), who suggest a cutoff value close to 0.95 for $\mathrm{CFI}$ and a cutoff value close to 0.06 for RMSEA are needed to conclude there is a relatively good fit between the hypothesized model and the observed data.

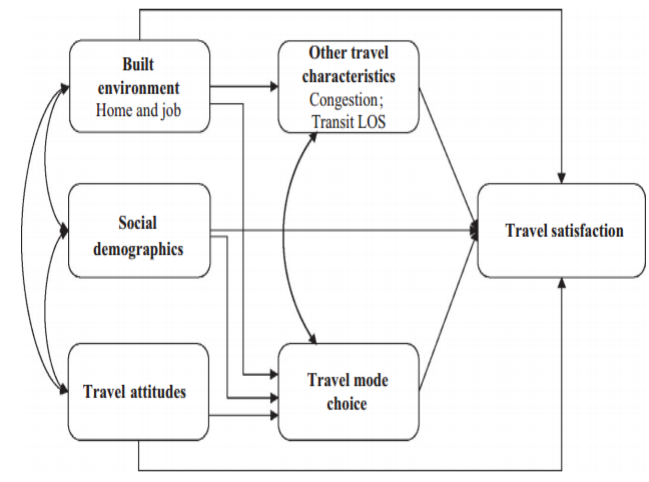

Figure 1: Model specification

\section{Effects of built environment on travel satisfaction}

Indirect effects on travel satisfaction via travel mode choice, the built environment may also influence travel satisfaction by affecting other travel characteristics. The model results suggested that living in a car-dependent environment was associated with higher levels of crowd in the bus or train carriage when commuting by transit. This is probably because of the high percentage of transit-dependent population located in suburban residential blocks, where fewer public transit services are available. Further, it is interesting to note that being close to greenery at home was associated with less congestion.

This is probably because there are fewer roads around the large green land lots and thus traffic volumes are relatively low. It is also possible that being close to greenery moderates the subjective assessment of the congestion. However, being close to greenery at the job location was associated with higher levels of crowding on transit and of congestion on roads. This is probably because job locations that are close to greenery are located around the city wall, which is a traffic bottleneck in Xi'an. In addition, people whose working location is close to transit stations were less likely to make a transfer when commuting by bus or rail transit. Finally, it is no surprise that longer home-job distances were associated with more transfers for transit commuters and more congestion on roads.

Age's influence to attitudes on built environment

Age proves to be an influencing factor and younger people stay more critical at architectural decay. The explanation rests in the fact that many older people have spent most of their life in a village (these generations have, mostly, grown up in villages, thus, have experienced the difficulties deriving from this way of life (i.e., lack of modern amenities, socially restricted lifestyle, lack of basic facilities in some cases, etc). To them, old traditional settlements reflect harshness, while modern constructions represent convenience and progress. On the other hand, younger generations seek for built environments that differ from their familiar urbanized ones; any modern-day building material or element typical of the urban environment appears highly odd in a traditional mountain settlement

Research analysis related to rural built environment

Built environment and culture depend on the following factors such as

- Natural resource

o Water

○ Rock and Soil

○ Jungle Environment

- Devotion

- Community

- Occupation

- Population density

- Natural disaster

The above factors are responsible for culture, which leads to built environment in rural areas. For instance, water plays a major role in building the environment. That is the reason where there is a variation in shelter from desert areas to jungle. From the natural resources, sustenance was varied as well as decides the occupation. The term culture is routine work followed for a long period with includes of devotional and community. Here the community is relating to the job or work done by the group of peoples 
3.0 Analysis based on various regions

\begin{tabular}{|c|c|c|c|c|}
\hline $\begin{array}{cl}1] & \text { S.N } \\
& \text { o }\end{array}$ & [2] Author Name & $\begin{array}{lll}\text { [3] } & \text { Case } & \text { study } \\
\text { location } & \\
\end{array}$ & $\begin{array}{l}\text { [4] Factors } \\
\text { considered }\end{array}$ & [5] Result concluded \\
\hline \multirow{3}{*}{1.} & \multirow{3}{*}{ [6] Srinivas (2015) } & $\begin{array}{l}\text { [7] Velnuthala is a } \\
\text { village in } \\
\text { Krishna District, } \\
\text { Andhra Pradesh, } \\
\text { India }\end{array}$ & [8] Occupation & \multirow{3}{*}{$\begin{array}{l}\text { [9] Culture is one of the most powerful } \\
\text { factors, which is guiding the } \\
\text { evolutionary pattern of settlements and } \\
\text { households }\end{array}$} \\
\hline & & $\begin{array}{l}\text { [10] Mangalagiri is a } \\
\text { town, in Guntur } \\
\text { District of } \\
\text { Andhra Pradesh, } \\
\text { India }\end{array}$ & $\begin{array}{l}\text { [11] Occupation } \\
\text { [12] Devotion }\end{array}$ & \\
\hline & & $\begin{array}{lr}\text { [13] Dichpally is } \\
\text { located } \\
\text { Nizamabad } \\
\text { district in the } \\
\text { state } \\
\text { Telangana }\end{array}$ & $\begin{array}{l}\text { [14] Occupation and } \\
\text { caste }\end{array}$ & \\
\hline 2. & $\begin{array}{l}{[15] \text { Sun et al. }} \\
(2017)\end{array}$ & $\begin{array}{l}\text { [16] A two or three } \\
\text { parks } \\
\text { randomly } \\
\text { selected } \\
\text { Shanghai }\end{array}$ & $\begin{array}{l}\text { [17] Occupation/ job } \\
\text { location }\end{array}$ & $\begin{array}{l}\text { [18] The residential built environment } \\
\text { characteristics are more influential on } \\
\text { commute behavior in Shanghai than } \\
\text { the built environment characteristics at } \\
\text { job locations }\end{array}$ \\
\hline 3. & $\begin{array}{c}\text { [19] Rankavat and } \\
\text { Tiwari (2016) }\end{array}$ & [20] Delhi, India & $\begin{array}{c}\text { [21] Risk perception } \\
\text { of pedestrians }\end{array}$ & $\begin{array}{l}\text { [22] Built environment plays in safety } \\
\text { outcomes and in the formation of } \\
\text { perceptions around those outcomes. }\end{array}$ \\
\hline 4. & $\begin{array}{l}\text { [23] Giannakopoulo } \\
\text { u and } \\
\text { Kaliampakos } \\
\text { (2016) }\end{array}$ & $\begin{array}{l}\text { [24] Mountain } \\
\text { regions in Greece }\end{array}$ & [25] Cultural heritage & $\begin{array}{l}\text { [26] The better-preserved built heritage } \\
\text { generates higher affection for } \\
\text { protection. Social attitudes provide key } \\
\text { elements of a regional policy on built } \\
\text { heritage preservation and } \\
\text { management. }\end{array}$ \\
\hline 5. & $\begin{array}{l}\text { [27] Etminani-Ghas } \\
\text { rodashti and } \\
\text { Ardeshiri } \\
\text { (2016) }\end{array}$ & $\begin{array}{l}\text { [28] } 22 \text { residential } \\
\text { areas in the } \\
\text { metropolitan of } \\
\text { Shiraz, Iran }\end{array}$ & $\begin{array}{l}\text { [29] Travel behaviors } \\
\text { based on } \\
\text { occupation }\end{array}$ & $\begin{array}{l}\text { [30] The level of public knowledge toward } \\
\text { travel behavior could notably improve } \\
\text { the efficiency of policies designed to } \\
\text { integrate land use and transportation } \\
\text { planning }\end{array}$ \\
\hline 6. & $\begin{array}{c}\text { [31] Shen et al. } \\
(2015)\end{array}$ & $\begin{array}{l}\text { [32] Shangdi-Qinghe, } \\
\text { a suburban town } \\
\text { in the northwest } \\
\text { of Beijing, china }\end{array}$ & $\begin{array}{l}\text { [33] Based on } \\
\text { communities }\end{array}$ & $\begin{array}{l}\text { [34] The influences of the built } \\
\text { environments at residential place and } \\
\text { activity place are different, and the } \\
\text { relationships between space-time } \\
\text { fixity and the built environments of } \\
\text { different community types are different }\end{array}$ \\
\hline 7. & $\begin{array}{l}\text { [35] Cao and Yang } \\
\text { (2017) }\end{array}$ & $\begin{array}{l}\text { [36] Guangzhou, } \\
\text { China }\end{array}$ & $\begin{array}{l}\text { [37] Based on } \\
\text { Transportation } \\
\text { and } \mathrm{CO}_{2} \\
\text { emissions }\end{array}$ & $\begin{array}{l}\text { [38] Effects of the built environment was } \\
\text { determined such as trip distance (TD), } \\
\text { motorized travel distance (MTD), etc. }\end{array}$ \\
\hline 8. & $\begin{array}{c}\text { [39] Qin et al. } \\
\text { (2017) }\end{array}$ & $\begin{array}{l}\text { [40] Yangtze River } \\
\text { Delta of eastern } \\
\text { China }\end{array}$ & [41]Landscape & $\begin{array}{l}\text { [42] The average annual increase of } \\
\text { built-up areas was about } 80 \mathrm{~km} 2 \text { per } \\
\text { year. The built-up maps could refine } \\
\text { current impervious surface products } \\
\text { generated by optical images and } \\
\text { prompt their improvement. }\end{array}$ \\
\hline
\end{tabular}




\section{DISCUSSION}

Numerous studies have examined the construction of culture led policies in urban contexts, especially in large cities. However, less is known about the construction of such policies in small towns and rural places (Lorentzen \& Van Heur, 2011).

Culture is generally emphasized as a medium for attracting tourists, investors, entrepreneurs, and highly trained workforces. Culture should enhance place attractiveness and strengthen the potential for consumption through the provision of different cultural and entertainment offers, social meeting places, cultural festivals, spectacular architecture, and artistic monuments. One way of doing this is through the regeneration of old production sites into postindustrial consumption sites, while another is place branding and marketing (Mommaas, 2004). Sacco et al. (2014) relate these strategies to the creative class perspective (Florida, 2002, 2005) on place attractiveness toward high-skilled labor, knowledge-based entrepreneurship, innovation, and high-tech investments. Tourism is a substantial part of this place attraction strategy too (Judd \& Fainstein, 1999).

Compared to the studies and effort related to urban buildings, the conditions and issues of rural buildings have not been given enough attention, or have even been ignored, for many years. As a result, comprehensive, detailed data on rural-building energy consumption is largely lacking (Shan et al., 2015).

First, culture is the meaning created by people in order to make sense of the world. It is the means, by which people receive, organize, rationalize, and understand their experiences. Social interaction is essential to understand culture because people continually create and recreate culture through their social interactions, rather than culture being something that is imposed on them. Behavior is made meaningful by interpretation; therefore social interaction depends on interpretation. There is always interplay between culture and agency. People's meanings their subjectivities, values, beliefs, ideas, and opinions arise out of interactions with other people and are constructed out of the discourses available to them. Culture is achieved by a subtle interweaving of many different threads of discourse (Cohen, 1985; Saleebey, 1994; Burr, 1995).

In the last two decades there has been increased interest in how people construct spaces and places, and how they instill meaning into certain places, and there has been considerable debate about what is rural (Bell, 2007). It has been argued that rural cannot be defined by trying to objectify it, and so the search for one generalized rural culture is replaced by a concern about how places are made, multiple meanings and identities in a place, and how dominance of certain meanings and identities are maintained and sustained in particular places at particular times (Philo, 1992; Whatmore et al., 1994; Murdoch \& Pratt, 1993; Little et al., 2005; Martinez-Brawley, 2001). Consequently, rural has not been viewed merely as a territorial, population, materialist definition (Bell, 2007) . It also consists of symbolic constructions that incorporate meanings, ideas, and experiences (Cohen, 1982; Hughes, 1997; Halfacree, 1993; Bell, 2007).

Rural spaces are not containers or backdrops wherein various processes of rural change take place; instead, they play an important role in forming and mediating these complex processes (see Woods (2003); Halfacree (2006). As Woods (2005) argues more broadly, the reconstitution of various rural relations can greatly shape people's lived experiences and practices in/of rural places. Hence, it is of importance to examine the formation of villagers' agency in wider socio-spatial conditions before directly delving into the complex interactions between the state and rural residents. In so doing, a more nuanced understanding of the complexity and flexibility of local people's interactions with the state in rural cultural governance can be gained.

\section{CONCLUSION}

Culture is one of the powerful factors that play a major role in built environment. From the analysis, it is found that culture is a regular activities followed for many generation which created a community and devotion. Based on culture, Built environment is analyzed by reviewing various approaches proposed in different location. Some of the most common factor for built environment in rural areas is natural resource, devotion, community and natural disaster. The reason for considering the entire built environment is that the rural settlement is an organism comprising of humans and the environment. The building is not the most important part of this organism. Rural residents do not spend as much time in buildings as urban residents do. The sustainability of a rural settlement is more related to the community and surrounding environment. Therefore, in this study, the built environment of poor rural areas also includes several components:

- Buildings (residential buildings, public buildings, etc.)

- Infrastructure (transportations, communications, power supplies, water supplies, markets, squares, landscape, etc.)

- Production facilities (farmland, livestock pens, etc.).

\section{REFERENCES}

1. Bell, M.M. (2007). The two-ness of rural life and the ends of rural scholarship. Journal of Rural Studies. [Online]. 23 (4). p.pp. 402-415. Available http://linkinghub.elsevier.com/retrieve/pii/S0743016707000241.

2. Borg, J. van der \& Russo, A.P. (2005). The Impacts of Culture on The Economic Development of Cities. [Online]. Available from: https://www.wien.gv.at/meu/fdb/pdf/intern-vergleichsstudie-ci-959-ma2 7.pdf.

3. Burr, V. (1995). An Introduction to Social Constructionism. London: Routledge.

4. CABE Space (2002). The Value of Good Design: How Buildings and Spaces create Economic and Social Value. [Online]. 2002. Designcouncil. Available from: http://www.publichealth.ie/files/file/Health_Impacts_of_the_Built_Envi ronment_A_Review.pdf. [Accessed: 12 April 2017].

5. Cao, X. \& Yang, W. (2017). Examining the effects of the built environment and residential self-selection on commuting 
trips and the related CO 2 emissions: An empirical study in Guangzhou, China. Transportation Research Part D: Transport and Environment. [Online]. 52. p.pp. 480-494. Available from: http://linkinghub.elsevier.com/retrieve/pii/S1361920915302455.

6. Cohen, A. (1982). Belonging: the experience of culture. In: A. Cohen (ed.). Belonging: Identity and Social Organisation in British Rural Cultures. Manchester: Manchester University Press.

7. Cohen, A. (1985). The Symbolic Construction of Community. England. Ellis Horwood Limited.

8. Davies, S. (1999). Subcultural explanations and interpretations of school deviance. Aggression and Violent Behaviour. [Online]. 4 (2). p.pp. 191-202. Available

from: http://www.publichealth.ie/files/file/Health_Impacts_of_the_Built_Envi ronment_A_Review.pdf.

9. Etminani-Ghasrodashti, R. \& Ardeshiri, M. (2016). The impacts of built environment on home-based work and non-work trips: An empirical study from Iran. Transportation Research Part A: Policy and Practice. [Online]. 85. p.pp. 196-207. Available from: http://linkinghub.elsevier.com/retrieve/pii/S0965856416000227.

10. Feng, J., Dijst, M., Prillwitz, J. \& Wissink, B. (2013). Travel Time and Distance in International Perspective: A Comparison between Nanjing (China) and the Randstad (The Netherlands). Urban Studies. [Online]. 50 (14). p.pp. 2993-3010. Available from: http://journals.sagepub.com/doi/10.1177/0042098013482504.

11. Feng, J., Dijst, M., Wissink, B. \& Prillwitz, J. (2014). Understanding Mode Choice in the Chinese Context: The Case of Nanjing Metropolitan Area Tijdschrift voor economische en sociale geografie. [Online]. 105 (3) p.pp. 315-330. Available from: http://doi.wiley.com/10.1111/tesg.12068.

12. Future Healthcare Network (2003). Investing in Design: Developing a Business Case for Good Design in Health. London: NHS Confederation.

13. Giannakopoulou, S. \& Kaliampakos, D. (2016). The social aspects of rural, mountainous built environment. Key elements of a regional policy planning. Journal of Cultural Heritage. [Online]. 21. p.pp. 849-859. Available http://linkinghub.elsevier.com/retrieve/pii/S1296207416300826.

14. Halfacree, H.K. (2006). Rural space: constructing a three-fold architecture. In: P. Cloke, T. Marsden, \& H. . Mooney (eds.). Handbook of Rural Studies. London: Sage.

15. Halfacree, K.H. (1993). Locality and social representation: Space, discourse and alternative definitions of the rural. Journal of Rural Studies. [Online]. 9 (1). p.pp. 23-37. Available from: http://linkinghub.elsevier.com/retrieve/pii/0743016793900033.

16. Head, L., Trigger, D. \& Mulcock, J. (2005). Culture as Concept and Influence in Environmental Research and Management. conservation and society. [Online]. 3 (2). p.pp. 251-264. Available from: http://www.conservationandsociety.org/article.asp?issn=0972-4923;yea $\mathrm{r}=2005$; volume $=3$; issue $=2$; spage $=251$; epage $=264$; aulast $=$ Head .

17. Hu, L. \& Bentler, P.M. (1999). Cutoff Criteria For Fit Indexes In Covariance Structure Analysis: Conventional Criteria Versus New Alternatives. Structural Equation Modeling: A Multidisciplinary Journal. 6 (1). p.pp. 1-55

18. Hughes, A. (1997). Women and rurality: gendered experiences of community in village life. In: P. Milbourne (ed.). Revealing Rural Other - Representation, Power and Identity in the British Countryside. London: Pinter.

19. Jayasudha, P., Dhanasekaran, M., Monsingh, D., Devadas \& Ramachandran, N. (2014). A study on sustainable design principles: A case study of a vernacular dwelling in Thanjavur region of Tamil Nadu, India. Indian Journal of Traditional Knowledge. [Online]. 13 (4). p.pp 762--770. Available http://indianmedicine.eldoc.ub.rug.nl/root/J4/45j/.

20. Judd, D.. \& Fainstein, S.. (1999). The Tourist City. CT/London: Yale University Press.

21. Lavin, T., Higgins, C., Metcalfe, O. \& Jordan, A. (2006). Health Impacts of the Built Environment: A review. [Online]. Ireland. Available from: http://www.publichealth.ie/files/file/Health_Impacts_of_the_Built_Envi ronment_A_Review.pdf.

22. Little, J., Panelli, R. \& Kraack, A. (2005). Women's fear of crime: A rural perspective. Journal of Rural Studies. [Online]. 21 (2). p.pp. 151-163. Available http://linkinghub.elsevier.com/retrieve/pii/S074301670500015X.

23. Liu, D., Zhu, C. \& Yang, Y. (2014a). The characteristics of resident commuting and its relationship with urban spatial structure in large cities of Western China: a case study of Chengdu. Human Geography. 29 (2). p.pp. 61-68.

24. Liu, Z., Deng, W. \& Ji, Y. (2014b). Influence of land use characteristics and trip attributes on commuting mode choice: A case of Nanjing. Journal of Southeast University. 30 (1). p.pp. 107-112.

25. Lorentzen, A. \& Van Heur, B. (2011). Cultural Political Economy of Small Cities. In: Cultural Political Economy of Small Cities. [Online].

Routledge, pp. $1-14$ Available

http://www.tandfebooks.com/isbn/9780203803844.

26. Lysgård, H.K. (2016). The 'actually existing' cultural policy and culture-led strategies of rural places and small towns. Journal of Rural Studies. [Online]. 44. p.pp. 1-11. Available from: http://linkinghub.elsevier.com/retrieve/pii/S0743016715300656

27. Ma, J. \& Wang, S. (2015). AcconPred: Predicting Solvent Accessibility and Contact Number Simultaneously by a Multitask Learning Framework under the Conditional Neural Fields Model. BioMed Research International. [Online]. 2015. p.pp. 1-10. Available from: http://www.hindawi.com/journals/bmri/2015/678764/.

28. Martinez-Brawley, E.E. (2001). Searching Again and Again. Inclusion, Heterogeneity and Social Work Research. The British Journal of Socia Work. 31 (2). p.pp. 271-285.

29. Mommaas, H. (2004). Cultural Clusters and the Post-industrial City: Towards the Remapping of Urban Cultural Policy. Urban Studies. [Online]. 41 (3). p.pp. 507-532. Available from: http://journals.sagepub.com/doi/10.1080/0042098042000178663.

30. Murdoch, J. \& Pratt, A.C. (1993). Rural studies: Modernism, postmodernism and the 'post-rural'. Journal of Rural Studies. [Online]. 9 (4). p.pp. 411-427. Available from: http://linkinghub.elsevier.com/retrieve/pii/074301679390053M.

31. Opoku, A. (2015). The Role of Culture in a Sustainable Built Environment. In: [Online]. pp. 37-52. Available from: http://link.springer.com/10.1007/978-3-319-14002-5_3.

32. Pacheco-Torgal, F. (2017). High tech startup creation for energy efficien built environment. Renewable and Sustainable Energy Reviews. [Online]. 71. p.pp. 618-629. Available from: http://linkinghub.elsevier.com/retrieve/pii/S1364032116311443.

33. Philo, C. (1992). Neglected rural geographies: A review. Journal of Rural Studies. [Online]. 8 (2). p.pp. 193-207. Available from http://linkinghub.elsevier.com/retrieve/pii/074301679290077J.

34. Pomponi, F. \& Moncaster, A. (2017). Circular economy for the built environment: A research framework. Journal of Cleaner Production. [Online]. 143. p.pp. 710-718. Available from: http://linkinghub.elsevier.com/retrieve/pii/S0959652616321102.

35. Qin, Y., Xiao, X., Dong, J., Chen, B., Liu, F., Zhang, G., Zhang, Y., Wang, J. \& Wu, X. (2017). Quantifying annual changes in built-up area in complex urban-rural landscapes from analyses of PALSAR and Landsat images. ISPRS Journal of Photogrammetry and Remote Sensing. [Online]. 124. p.pp. 89-105. Available from: http://linkinghub.elsevier.com/retrieve/pii/S0924271616302775.

36. Rankavat, S. \& Tiwari, G. (2016). Pedestrians risk perception of traffic crash and built environment features - Delhi, India. Safety Science. [Online]. $87 . \quad$ p.pp. 1-7. Available from: http://linkinghub.elsevier.com/retrieve/pii/S0925753516300157.

37. Sacco, P., Ferilli, G. \& Blessi, G.T. (2014). Understanding culture-led local development: A critique of alternative theoretical explanations. Urban Studies. [Online]. 51 (13). p.pp. 2806-2821. Available from: http://journals.sagepub.com/doi/10.1177/0042098013512876.

38. Saleebey, D. (1994). Culture, Theory, and Narrative: The Intersection of Meanings in Practice. Social Work. 39 (4). p.pp. 351-359.

39. Shan, M., Wang, P., Li, J., Yue, G. \& Yang, X. (2015). Energy and environment in Chinese rural buildings: Situations, challenges, and intervention strategies. Building and Environment. [Online]. 91. p.pp. 271-282. Available http://linkinghub.elsevier.com/retrieve/pii/S0360132315001250.

40. Shen, Y., Chai, Y. \& Kwan, M.-P. (2015). Space-time fixity and flexibility of daily activities and the built environment: A case study of different types of communities in Beijing suburbs. Journal of Transport Geography. [Online]. 47. p.pp. 90-99. Available from: http://linkinghub.elsevier.com/retrieve/pii/S0966692315001040.

41. Srinivas, D. (2015). Impact of Culture on Rural Built Environment. In: International Conference on IT, Architecture and Mechanical Engineering. [Online]. 2015, Dubai. Available from: http://iieng.org/images/proceedings_pdf/1515E0515004.pdf.

42. Sun, B., Ermagun, A. \& Dan, B. (2017). Built environmental impacts on commuting mode choice and distance: Evidence from Shanghai Transportation Research Part D: Transport and Environment. [Online] 52. p.pp. 441-453. Available from: http://linkinghub.elsevier.com/retrieve/pii/S136192091530239X.

43. Wallerstein, N., Duran, B.M., Aguilar, J., Joe, L., Loretto, F., Toya, A., Yepa-Waquie, H., Padilla, R. \& Shendo, K. (2003). Jemez Pueblo: built and social-cultural environments and health within a rural American Indian community in the Southwest. American journal of public health. [Online]. 93 (9). p.pp. 1517-8. Available from 
http://www.ncbi.nlm.nih.gov/pubmed/12948972.

44. Wang, D., Chai, Y. \& Li, F. (2011a). Built environment diversities and activity-travel behaviour variations in Beijing, China. Journal of Transport Geography. [Online]. 19 (6). p.pp. 1173-1186. Available from: http://linkinghub.elsevier.com/retrieve/pii/S096669231100041X.

45. Wang, D. \& Zhou, M. (2017). The built environment and travel behavior in urban China: A literature review. Transportation Research Part D: Transport and Environment. [Online]. 52. p.pp. 574-585. Available from: http://linkinghub.elsevier.com/retrieve/pii/S1361920915302650.

46. Wang, E., Song, J. \& Xu, T. (2011b). From 'spatial bond' to 'spatial mismatch': An assessment of changing jobs-housing relationship in Beijing. Habitat International. [Online]. 35 (2). p.pp. 398-409. Available from: http://linkinghub.elsevier.com/retrieve/pii/S0197397510000792.

47. Whatmore, S., Mardsen, T. \& Lowe, P. (1994). Gender and Rurality. London: David Fulton Publishers.

48. Woods, M. (2003). Deconstructing rural protest: the emergence of a new social movement. Journal of Rural Studies. [Online]. 19 (3). p.pp. 309-325. Available from: http://linkinghub.elsevier.com/retrieve/pii/S0743016703000081.

49. Woods, M. (2005). Rural Geography: Processes, Responses and Experiences in Rural Restructuring. London: Sage.

50. Yang, J. (2010). Spatial and Social Characteristics of Urban Transportation in Beijing. Transportation Research Record: Journal of the Transportation Research Board. [Online]. 2193. p.pp. 59-67. Available from: http://trijournalonline.trb.org/doi/10.3141/2193-08.

51. Yang, J., Shen, Q., Shen, J. \& He, C. (2012). Transport Impacts of Clustered Development in Beijing: Compact Development versus Overconcentration. Urban Studies. [Online]. 49 (6). p.pp. 1315-1331. Available from: http://journals.sagepub.com/doi/10.1177/0042098011410336.

52. Zhang, Y., Wu, W., Li, Y., Liu, Q. \& Li, C. (2014). Does the Built Environment Make a Difference? An Investigation of Household Vehicle Use in Zhongshan Metropolitan Area, China. Sustainability. [Online]. 6 (8). p.pp. 4910-4930. Available from: http://www.mdpi.com/2071-1050/6/8/4910/.

53. Zhao, P. (2014). The Impact of the Built Environment on Bicycle Commuting: Evidence from Beijing. Urban Studies. [Online]. 51 (5). p.pp. 1019-1037. Available from: http://journals.sagepub.com/doi/10.1177/0042098013494423.

54. Zhao, P. \& Lu, B. (2011). Managing urban growth to reduce motorised travel in Beijing: one method of creating a low-carbon city. Journal of Environmental Planning and Management. [Online]. 54 (7). p.pp. 959-977. Available from: http://www.tandfonline.com/doi/abs/10.1080/09640568.2010.547684.

55. Zhao, P., Lü, B. \& de Roo, G. (2010). Urban Expansion and Transportation: The Impact of Urban form on Commuting Patterns on the City Fringe of Beijing. Environment and Planning A. [Online]. 42 (10) p.pp. 2467-2486. Available from: http://journals.sagepub.com/doi/10.1068/a4350.

56. Zhao, Y. \& Chai, Y. (2013). Residents' activity-travel behavior variation by communities in Beijing, China. Chinese Geographical Science. [Online]. 23 (4). p.pp. 492-505. Available from: http://link.springer.com/10.1007/s11769-013-0616-7.

\section{AUTHORS PROFILE}

Srinivas Daketi Assistant Professor, Department of Architecture, School of Planning and Architecture Vijayawada.

Dr.AbdulRazak Mohamed Professor, Department of Architecture, School of Planning and Architecture Vijayawada.

Dr.RameshSrikonda Professor, Department of Architecture, School of Planning and Architecture Vijayawada. 